Original Article

\title{
Four active monomers from Moutan Cortex exert inhibitory effects against oxidative stress by activating Nrf2/Keap1 signaling pathway
}

\author{
Baoshun Zhang ${ }^{\#, *}$, Deqing Yü, Nanxuan Luo, Changqing Yang, and Yurong Zhu \\ College of Pharmaceutical Sciences, Southwest University, Beibei, Chongqing 400716, P. R. China
}

\section{ARTICLE INFO}

Received January 2, 2020

Revised June 9, 2020

Accepted July 21, 2020

\section{*Correspondence \\ Baoshun Zhang \\ E-mail: zbs360@swu.edu.cn}

\section{Key Words}

Kelch like ECH-associated protein 1

Liver failure

Nuclear factor E2-related factor 2

Oxidative stress

Signal transduction

\#These authors contributed equally to this work.

\begin{abstract}
Paeonol, quercetin, $\beta$-sitosterol, and gallic acid extracted from Moutan Cortex had been reported to possess anti-oxidative, anti-inflammatory, and antitumor activities. This work aimed to illustrate the potential anti-oxidative mechanism of monomers in human liver hepatocellular carcinoma (HepG2) cells-induced by hydrogen peroxide $\left(\mathrm{H}_{2} \mathrm{O}_{2}\right)$ and to evaluate whether the hepatoprotective effect of monomers was independence or synergy in mice stimulated by carbon tetrachloride $\left(\mathrm{CCl}_{4}\right)$. Monomers protected against oxidative stress in HepG2 cells in a doseresponse manner by inhibiting the generation of reactive oxygen species, increasing total antioxidant capacity, catalase and superoxide dismutase (SOD) activities, and activating the antioxidative pathway of nuclear factor E2-related factor 2/Kelchlike ECH-associated protein 1 (Nrf2/Keap1) signaling pathway. We found that the in vitro antioxidant capacities of paeonol and quercetin were better than those of $\beta$-sitosterol and gallic acid. Furthermore, paeonol apparently diminished the levels of alanine transaminase and aspartate aminotransferase, augmented the contents of glutathione and SOD, promoted the expressions of Nrf2 and heme oxygenase- 1 proteins in mice stimulated by $\mathrm{CCl}_{4}$. In $\mathrm{HepG} 2$ cells, paeonol, quercetin, $\beta$-sitosterol, and gallic acid play a defensive role against $\mathrm{H}_{2} \mathrm{O}_{2}$-induced oxidative stress through activating Nrf2/Keap1 pathway, indicating that these monomers have anti-oxidative properties. Totally, paeonol and quercetin exerted anti-oxidative and hepatoprotective effects, which is independent rather than synergy.
\end{abstract}

\section{INTRODUCTION}

Oxidative stress breaking prooxidant-antioxidant balance in the body leads to oxidizing. The prooxidant/antioxidant dysfunction is due to excessive accumulation of reactive oxygen species (ROS). The burden of endogenous antioxidant defense is primarily provided by enzymes such as superoxide dismutase (SOD), catalase (CAT), glutathione peroxidase (GSH-Px), and nonenzymatic substances [1,2]. Additionally, oxidative stress affects cell viability, destroys cell structures, and ultimately leads to cell death [3]. Oxidative stress is closely associated with several age-related chronic diseases, including cancer, Alzheimer's, Parkinson, and heart diseases [4]. Oxidative stress is an important cause of liver injury, $\mathrm{CCl}_{4}$ has been widely used to study hepatotoxicity both in vitro and in vivo. $\mathrm{CCl}_{4}$ is metabolized into trichloromethyl radical by CYP450 in the liver, and later trichloromethyl is converted to trichloromethyl peroxyl radical in aerobic conditions. These peroxidation radicals induce lipid peroxidation, destroy the structure of cell membrance, release indicators of aspartate aminotransferase (AST) and alanine transaminase (ALT), and ultimately lead to liver injury of mice [5]. Thus, it is necessary to find some promising candidate drugs to resist oxidative damage.
This is an Open Access article distributed under the terms of the Creative Commons Attribution Non-Commercial License, which permits unrestricted non-commercial use, distribution, and reproduction in any medium, provided the original work is properly cited. Copyright @ Korean J Physiol Pharmacol, pISSN 1226-4512, elSSN 2093-3827
Author contributions: B.Z. designed the research and D.Y. provided suggestions for research and performed most of the experiments, with the assistance of N.L. and C.Y. analyzed the data. Y.Z. contributed analytic tools. D.Y. wrote the primary manuscript and B.Z. revised the manuscript. 
The current evidence demonstrates that a key transcription factor for the endogenous antioxidative enzyme, nuclear factor E2related factor 2 (Nrf2), is a target for oxidant insults and apoptosis [6]. Under physiological conditions, Kelch-like ECH-associated protein 1 (Keapl) enables rapidly ubiquitination and degradation of Nrf2. However, in some circumstances, Nrf2 activators trigger the separation of Nrf2 from Keapl and enter into the nucleus, resulting in the formation of a binding complex between Nrf2 and antioxidant-responsive element (ARE), and the promotion of the expressions of $\mathrm{NAD}(\mathrm{P}) \mathrm{H}$ quinone oxidoreductase 1 (NQO1) and heme oxygenase-1 (HO-1) [7]. This redox regulation in the oxidative stress response and signaling has been used to screen novel alternative agents for antioxidative effects.

Moutan Cortex (MC) exerts the pharmacological activities of antioxidation, anti-inflammation, removing blood stasis, dredging meridian, and expelling pus [8-10]. The main bioactive ingredients of $\mathrm{MC}$ consist of paeonol, gallic acid, quercetin, $\beta$-sitosterol, and paeoniol [11,12]. Paeonol eliminating ligationinduced periodontitis in rat was through the regulation of the Nrf2/NF- $\kappa$ B/NFATc1 signaling [13]. Gallic acid inhibiting tertbutyl hydroperoxide-induced hepatotoxicity was by activating the extracellular signal-regulated kinase-Nrf2-Keap1-mediated antioxidative response [14]. Quercetin was recognized as a potential hepatoprotective agent in the treatment of mice liver injury induced by lipopolysaccharide/D-galactosamine (LPS/D-GalN) [15]. However, a little information is available concerning the independent or synergistic effects of four active monomers on the hepatoprotective effects. Additionally, the inhibitory mechanisms of those compounds against oxidative damage and liver injury are unknown. Therefore, the aims of the present study are to evaluate the possible mechanisms of four monomers (paeonol, quercetin, $\beta$-sitosterol, and gallic acid) against hydrogen peroxide $\left(\mathrm{H}_{2} \mathrm{O}_{2}\right)$-induced oxidative damage in human liver hepatocellular carcinoma (HepG2) cells and against carbon tetrachloride $\left(\mathrm{CCl}_{4}\right)$ induced liver injury in mice, and to further elucidate whether the effects of these monomers are independent or synergistic.

\section{METHODS}

\section{Reagents and equipment}

MC was purchased from the traditional herbal market in Dianjiang (Chongqing, China). Ethyl acetate, methanol, ethanol were obtained from Chongqing Taixin Chemical Reagent Co., Ltd. (Chongqing, China). $\mathrm{H}_{2} \mathrm{O}_{2}$ (30\%) was purchased from Chongqing East Chemical (Group) Co., Ltd. (Chongqing, China). HepG2 cells were obtained from Beijing Beina Chuanglian Biotechnology Research Institute (Beijing, China). Antibodies against $\beta$-actin, Nrf2, HO-1, NQO1, Keap1, LaminB, and glyceraldehyde-3-phosphate dehydrogenase (GAPDH) were obtained from Proteintech Group, Inc. (Wuhan, China). CCK-8 kits were purchased from
Selleck Chemicals (Shanghai, China). Total antioxidant capacity (T-AOC), CAT and SOD kits were acquired from Sino Best Biological Technology Co., Ltd. (Shanghai, China). ALT and AST and reduced GSH kits were purchased from Nanjing Jiancheng Institute of Biological Engineering (Nanjing, China). Electrophoretic mobility shift assay (EMSA) kits and the biotin-labeled probe ARE were obtained from Beyotime (Shanghai, China).

\section{Extraction, isolation, identification of monomers from MC}

Air-dried MC (250 g) was crushed and extracted with $85 \%$ ethanol for $24 \mathrm{~h}$ and ultrasound for $1 \mathrm{~h}$. The combined extracts were concentrated in vacuo under reduced pressure and were then successively partitioned with different extract reagents, including petroleum ether, ethyl acetate, and n-butanol fraction. The fractions were performed on a silica gel column to separate and purified. Separation of the extract on a silica gel column obtained four monomers, and their structures were confirmed with spectral data from mass spectra (MS), ${ }^{13} \mathrm{CNMR}$, and ${ }^{1} \mathrm{HNMR}$.

\section{Cell culture}

HepG2 cells were cultured in DMEM containing 15\% (V/V) FBS, penicillin (100 U/ml), and streptomycin $(100 \mathrm{U} / \mathrm{ml})$ (Sijiqing, Zhejiang, China) in a humidified incubator at $37^{\circ} \mathrm{C}$ under $5 \%$ $\mathrm{CO}_{2}$. HepG2 cells were passaged at a ratio of 1:2 or 1:3 when the cells grew to more than $80 \%$ confluence.

\section{Cell viability assay}

HepG2 cells were transferred onto 96-well culture plates at a density of $5 \times 10^{3}$ cells per well. After a $48 \mathrm{~h}$ incubation, the cells were divided into four groups: control, $\mathrm{H}_{2} \mathrm{O}_{2}$, chemicals, and positive control (vitamin $\mathrm{E}$ ). The control group was not treated with chemicals or $\mathrm{H}_{2} \mathrm{O}_{2}$. The $\mathrm{H}_{2} \mathrm{O}_{2}$ group was treated with different concentrations of $\mathrm{H}_{2} \mathrm{O}_{2}(3,4,5,6,7,8,9,10$, or $12 \mathrm{mM})$ for 24 $\mathrm{h}$ to screening molding concentration. The chemical and positive control groups were pretreated with different monomers (paeonol, quercetin, $\beta$-sitosterol, gallic acid, and vitamin $\mathrm{E}$ ) with 10 , 20,40 , and $80 \mu \mathrm{M}$ for $24 \mathrm{~h}$ to determine the dose concentration, respectively. Then, $1 / 10$ volume of CCK- 8 was directly added to the cell culture medium for 0.5 to $4 \mathrm{~h}$. Finally, the absorbance was measured by microplate reader at $450 \mathrm{~nm}$ (BioTeK, Winooski, VT, USA).

\section{Determination of ROS level of HepG2 cells induced by $\mathrm{H}_{2} \mathrm{O}_{2}$ after monomers pretreatment}

As described above in 2.4, the cells were stimulated with $7 \mathrm{mM}$ $\mathrm{H}_{2} \mathrm{O}_{2}$ for $5,15,30,60,120$, or $300 \mathrm{~min}$. In another 12-well plate, the cells were pretreated with monomers for $6 \mathrm{~h}$, and then they 
were incubated in the presence or absence of $7 \mathrm{mM} \mathrm{H}_{2} \mathrm{O}_{2}$ for 15 min. Finally, the cells were incubated with the DCFH-DA probe for $30 \mathrm{~min}$, and the cellular fluorescence was detected by a fluorescence microscope (Nikon, Tokyo, Japan).

\section{Determination of antioxidative markers after monomers pretreatment}

HepG2 cells were transferred onto 12-well culture plates at a density of $2.5 \times 10^{5}$ cells per well. After a $48 \mathrm{~h}$ incubation, the cells were separately pretreated with four monomers at $20 \mu \mathrm{M}$ for 6 $\mathrm{h}$ and were then incubated in the presence or absence of $7 \mathrm{mM}$ $\mathrm{H}_{2} \mathrm{O}_{2}$ for $24 \mathrm{~h}$. The antioxidative markers were determined by SOD, CAT, T-AOC, ALT, AST, and GSH assays kits after pretreatment with monomers.

\section{Preparation of relative proteins of HepG2 cells after monomers pretreatment}

Cells were respectively pretreated with $20 \mu \mathrm{M}$ of four monomers for $6 \mathrm{~h}$ and then were stimulated with $7 \mathrm{mM} \mathrm{H}_{2} \mathrm{O}_{2}$ for $24 \mathrm{~h}$. Total cellular proteins were extracted by the protein extract kits (KeyGEN Biotech, Jiangsu, China). Cells were separately pretreated with $20 \mu \mathrm{M}$ of monomers for $3 \mathrm{~h}$, and later were stimulated with $7 \mathrm{mM} \mathrm{H}_{2} \mathrm{O}_{2}$ for $3 \mathrm{~h}$, the cytosolic and nuclear proteins were extracted by the protein extract kits. The relative proteins were stored at $-80^{\circ} \mathrm{C}$ for analysis.

\section{Western blot analysis}

The whole-cell lysates or nuclear/cytosolic proteins were separated by $10 \%$ or $12 \%$ SDS-PAGE and were transferred onto a polyvinylidene difluoride (PVDF) membrane. The membranes were blocked with $10 \%$ nonfat milk for $2 \mathrm{~h}$ and washed 5 times (5 min/wash) with the TBST solution. Next up, the PVDF membranes were incubated with different primary antibodies at $4^{\circ} \mathrm{C}$ overnight and washed. The membranes were incubated with the secondary antibody for $2 \mathrm{~h}$ and finally visualized using the ECL system (Beyotime Biotechnolgy, Shanghai, China).

\section{EMSA assay}

The EMSA assay was used to detect the binding of the protein to DNA. The ARE consensus oligo was as follows: $5^{\prime}$-ACT GAG GCT GAC TCA GCA AAA TC-3', 3'-TGA CTC CCA CTG AGT CGT TTT AG-5'. The nuclear Nrf2 protein combined with the ARE labeled probe. The free probe and bound macromolecular protein were segregated by EMSA and transferred to a magna nylon transfer membrane with positive electricity. The membrane was cross-linked by a ultraviolet (UV)-light cross-linker at 254 $\mathrm{nm}$, and the strips were tested with the ECL system.

\section{Effect of ML385 on the expression of Nrf2 protein of HepG2 cells}

ML385 interacts with Nrf2 to inhibit the levels of Nrf2. HepG2 cells were cultured in 6 -well plates at $2.5 \times 10^{5}$ cells $/ \mathrm{ml}$ for $48 \mathrm{~h}$. The cells were first treated with $2.5 \mu \mathrm{M}$ ML385 for $1 \mathrm{~h}$ and later with $20 \mu \mathrm{M}$ of the monomers in the chemical group for $6 \mathrm{~h}$. Finally, $7 \mathrm{mM} \mathrm{H}_{2} \mathrm{O}_{2}$ was added to the cells for $24 \mathrm{~h}$. The cellular proteins were separately extracted for analysis.

\section{Animals, treatment and tissue preparation}

Male Kunming mice ( $22 \pm 2 \mathrm{~g}$ ) were purchased by Chongqing Medical University. All animal experiments were performed in accordance with the National Institutes of Health Guide for the Care and Use of Laboratory Animals. The animal studies were performed after receiving approval of the Institutional Animal Care and Use Committee (IACUC) in Southwest University, P.R.China (IACUC approval No. 11-2018). The mice were randomly divided into six groups: control; $2 \% \mathrm{CCl}_{4} ; 2 \% \mathrm{CCl}_{4}+100$ $\mathrm{mg} / \mathrm{kg}$ paeonol (paeonol); $2 \% \mathrm{CCl}_{4}+100 \mathrm{mg} / \mathrm{kg}$ quercetin (quercetin); $2 \% \mathrm{CCl}_{4}+50 \mathrm{mg} / \mathrm{kg}$ paeonol $+50 \mathrm{mg} / \mathrm{kg}$ quercetin (L(paeonol + quercetin)); and 2\% $\mathrm{CCl}_{4}+100 \mathrm{mg} / \mathrm{kg}$ paeonol +100 $\mathrm{mg} / \mathrm{kg}$ quercetin (H-(paeonol + quercetin)). The paeonol, quercetin, $\mathrm{L}$-(paeonol + quercetin), and $\mathrm{H}$-(paeonol + quercetin) groups were fed respectively with the monomers for a week. The control and $2 \% \mathrm{CCl}_{4}$ groups were given the same volume of $0.5 \%$ sodium carboxymethyl cellulose for a week. After that, all animals except the control mice were intraperitoneally injected with $2 \% \mathrm{CCl}_{4}(\mathrm{~V} /$ $\mathrm{V}$ in olive oil) for $24 \mathrm{~h}$. Blood samples were taken from the retroorbital venous plexus and were centrifuged at $12,000 \times \mathrm{g}, 4^{\circ} \mathrm{C}$ for $10 \mathrm{~min}$, and were stored at $-80^{\circ} \mathrm{C}$. The livers were harvested immediately and snap-frozen in liquid nitrogen for histopathology, immunohistochemistry, and western blot assays.

\section{Histopathology and immunohistochemical staining}

Liver tissue sections were fixed in $4 \%$ formalin and embedded in solid paraffin. The sections were mounted on silane-coated slides and stained with hematoxylin and eosin (H\&E). The slides were prepared in terms of the instructions of the histostain TMplus and diaminobenzidine (DAB) kits. These slides were incubated with $\mathrm{Nrf2}$ antibodies at $4^{\circ} \mathrm{C}$ overnight and were with biotinlabeled goat antirabbit IgG for $1 \mathrm{~h}$. Histopathological changes and the levels of protein expressions in livers were visualized by using a light microscope (magnification, 200x).

\section{Statistical analysis}

The comparison of the results was used the statistical package SPSS (ver. 20.0; IBM, Armonk, NY, USA). All data were presented as the mean \pm standard deviation. The data analysis was per- 
formed by one-way analysis of variance (ANOVA). Differences between groups were determined by significant difference test. $\mathrm{p}<0.05$ was considered significant, and $\mathrm{p}<0.01$ was considered extremely significant difference.

\section{RESULTS}

\section{Isolation and identification of four monomers from MC}

The isolation and purification of monomers from $\mathrm{MC}$ were obtained by a silica gel column. Retention factors $\left(\mathrm{R}_{\mathrm{f}}\right)$, melting point (Mp) and UV values were measured in Table 1 . Their structures were confirmed by ${ }^{1} \mathrm{H}$ NMR, ${ }^{13} \mathrm{C}$ NMR (Supplementary Fig. 1) and MS (Supplementary Fig. 2) spectra. The four monomers (1-4) were paeonol, quercetin, $\beta$-sitosterol, and gallic acid, respectively.

Compound $1{ }^{1} \mathrm{H}$ NMR $\left(400 \mathrm{MHz}, \mathrm{CDCl}_{3}, \delta \mathrm{ppm}\right): \delta 2.56(\mathrm{~s}, 3 \mathrm{H}$, $\left.-\mathrm{COCH}_{3}\right), 3.84$ (s, $3 \mathrm{H},-\mathrm{OCH}_{3}$ ), 6.42-7.64 (s, 3H, ArH), 12.75 (s, $1 \mathrm{H},-\mathrm{OH}) ;{ }^{13} \mathrm{C}$ NMR $\left(100 \mathrm{MHz}, \mathrm{CDCl}_{3}, \delta \mathrm{ppm}\right): \delta 202.54,166.14$, $165.30,132.27,113.94,107.62,100.87,55.55,26.12$. In comparison to the reference data [16], the ${ }^{1} \mathrm{H}$ NMR, ${ }^{13} \mathrm{C}$ NMR and MS data confirmed the white crystal was paeonol.

Compound $2{ }^{1} \mathrm{H}$ NMR $\left(400 \mathrm{MHz}, \mathrm{DMSO}-\mathrm{d}_{6}, \delta \mathrm{ppm}\right): \delta$ 6.19-7.68 (m, 5H, ArH), 12.49 (s, 1H, 5-OH); ${ }^{13} \mathrm{C}$ NMR (100 MHz, DMSO-d $_{6}, \delta$ ppm): $\delta 176.30,164.36,161.19,156.61,148.17,147.28$, $145.52,136.19,122.43,120.44,116.07,115.54,103.48,98.65,93.81$. In comparison to the reference data [17], the ${ }^{1} \mathrm{H} N M R,{ }^{13} \mathrm{C} N M R$ and MS data confirmed the yellow powder was quercetin.

Compound $3{ }^{1} \mathrm{H}$ NMR $\left(400 \mathrm{MHz}, \mathrm{CDCl}_{3} \delta \mathrm{ppm}\right): \delta 0.68(3 \mathrm{H}$, s, H-18), $0.84(3 \mathrm{H}, \mathrm{d}, J=6.2 \mathrm{~Hz}, \mathrm{H}-26), 0.85(3 \mathrm{H}, \mathrm{d}, J=6.5 \mathrm{~Hz}$, H-27), $1.01(3 \mathrm{H}, \mathrm{d}, J=6.0 \mathrm{~Hz}, \mathrm{H}-29), 1.25(3 \mathrm{H}, \mathrm{s}, \mathrm{H}-19), 3.52(1 \mathrm{H}$,

Table 1. Physical properties of active monomers from MC

\begin{tabular}{llcccc}
\hline Compound & \multicolumn{1}{c}{ Appearance } & $\begin{array}{c}\mathrm{R}_{\mathrm{f}} \text { (ethyl acetate:ethanol, } \\
\mathrm{V} / \mathrm{N}=20: 1)\end{array}$ & $\mathrm{Mp}\left({ }^{\circ} \mathrm{C}\right)$ & $\mathrm{UV}(\mathrm{nm})(\mathrm{EtOH})$ & {$[\mathrm{M}+\mathrm{H}]^{+}$} \\
\hline Paeonol & White needle-like crystal & 0.80 & $51.20-52.70$ & 270.2 & 167 \\
Quercetin & Yellow-green powder & 0.76 & $313-314.20$ & 258,375 & 302.05 \\
$\beta$-sitosterol & White powder & 0.73 & $139-142$ & 317.40 & 414.25 \\
Gallic acid & White powder & 0.48 & $235-240$ & $216,271,239$ & $173.05,169.90$ \\
\hline
\end{tabular}

MC, Moutan Cortex; $\mathrm{R}_{\mathrm{f}}$, Retention factor; Mp, melting point; UV, ultraviolet; EtOH, ethanol; $M$, molecular weight; $\mathrm{H}$, hydrogen.

A

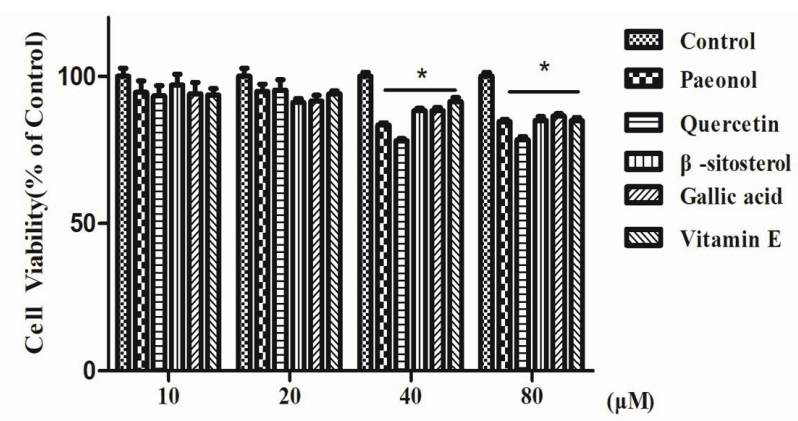

C

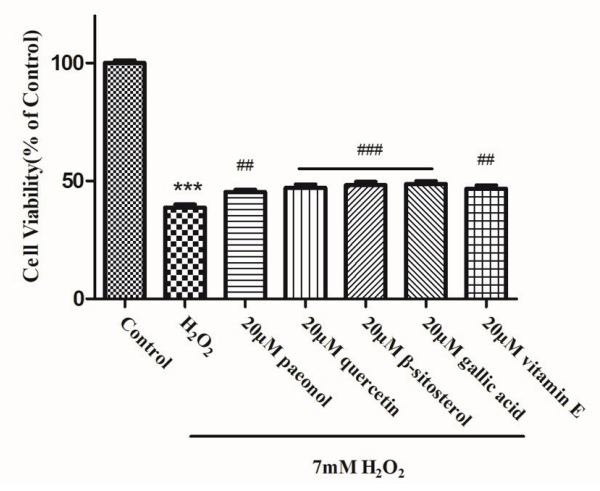

B

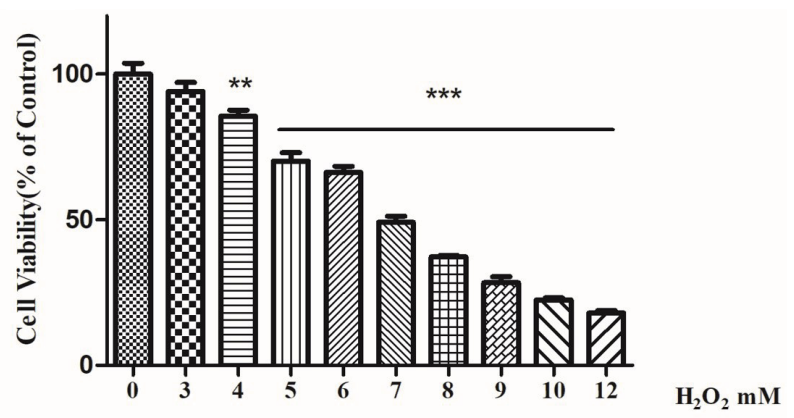

Fig. 1. Effects of four monomers and hydrogen peroxide $\left(\mathrm{H}_{2} \mathrm{O}_{2}\right)$ on cell viability of human liver hepatocellular carcinoma (HepG2) cells. (A) The effects of monomers (paeonol, quercetin, $\beta$-sitosterol, gallic acid, and vitamin E) on HepG2 cell viability. (B) The effect of $\mathrm{H}_{2} \mathrm{O}_{2}$ on HepG2 cell viability at different concentration of $\mathrm{H}_{2} \mathrm{O}_{2}$. (C) The effects of monomers on $\mathrm{HepG} 2$ cell viabilities at the concentration of $7 \mathrm{mM} \mathrm{H}_{2} \mathrm{O}_{2}$. The data from three independent experiments are presented as the mean \pm standard deviation. ${ }^{*} p<0.05,{ }^{* *} p<0.01$, and ${ }^{* * *} p<0.001$, the $\mathrm{H}_{2} \mathrm{O}_{2}$ vs. control group; ${ }^{\# \#} \mathrm{p}<0.01$, and ${ }^{\# \# \#} \mathrm{p}<0.001$, the monomers vs. $\mathrm{H}_{2} \mathrm{O}_{2}$ group. 


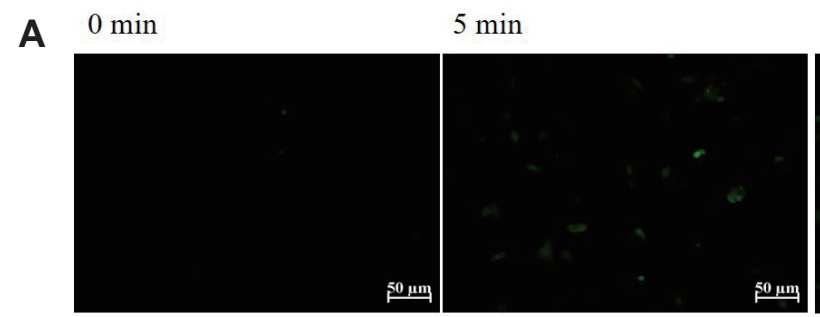

$15 \min$

$30 \mathrm{~min}$
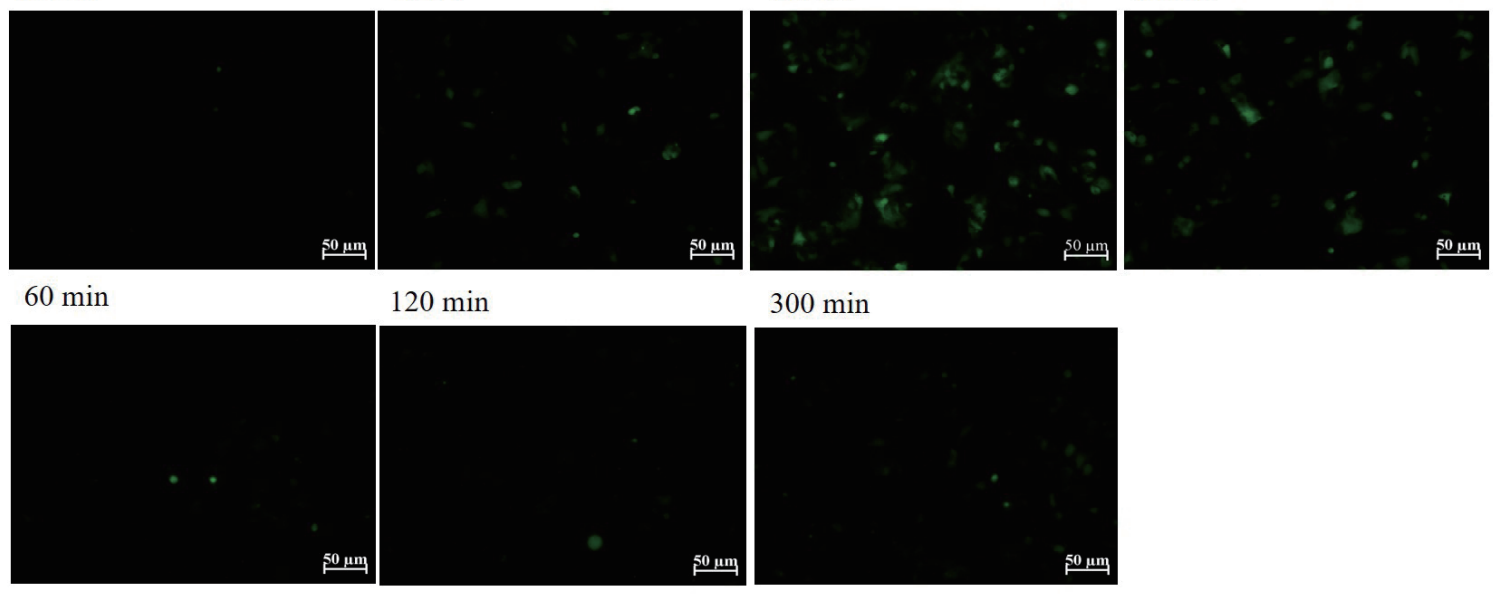

$300 \mathrm{~min}$

B

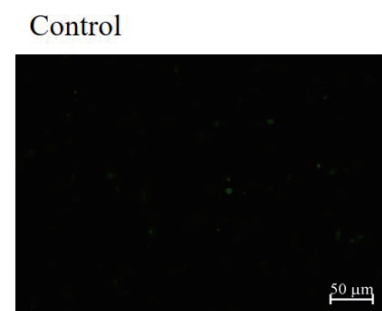

$\mathrm{H}_{2} \mathrm{O}_{2}$

$\mathrm{H}_{2} \mathrm{O}_{2}+$ paeonol

$\mathrm{H}_{2} \mathrm{O}_{2}+$ quercetin

$50 \mu \mathrm{m}$
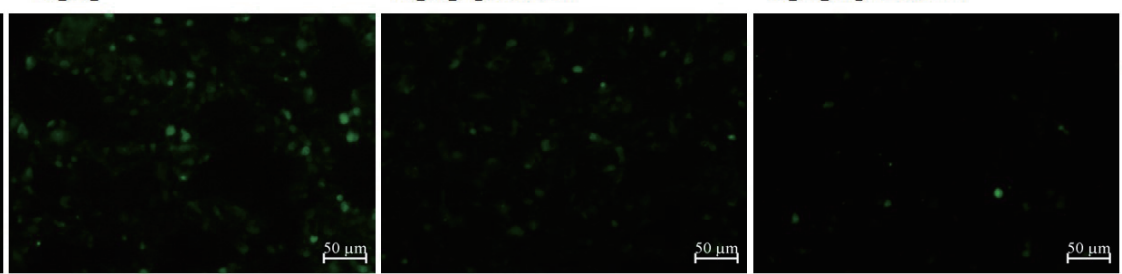

$\mathrm{H}_{2} \mathrm{O}_{2}+\beta$-sitosterol

$\mathrm{H}_{2} \mathrm{O}_{2}+$ gallic acid

$\mathrm{H}_{2} \mathrm{O}_{2}$ +vitamin $\mathrm{E}$
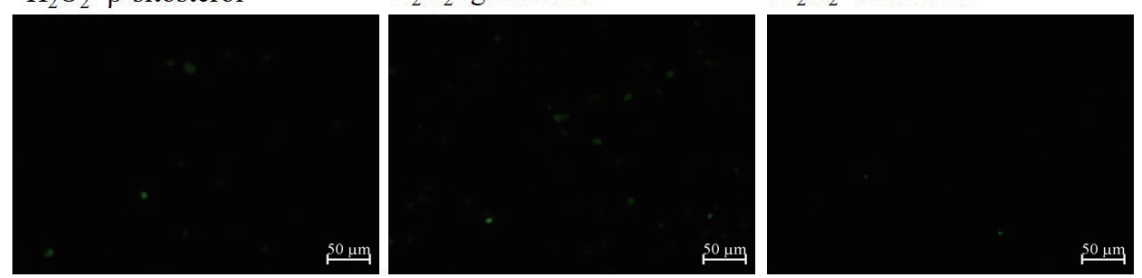

C

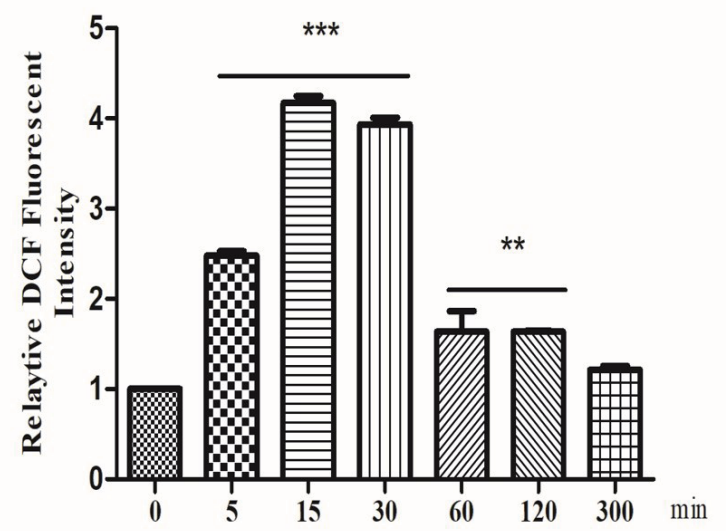

D

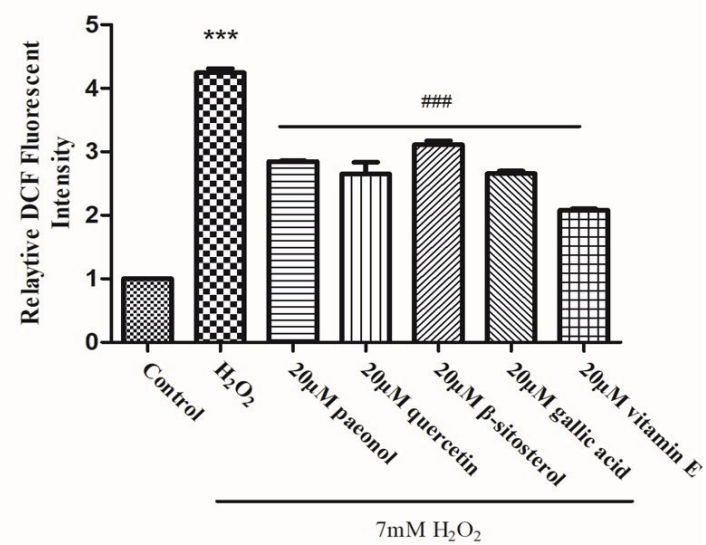

Fig. 2. Effects of four monomers on reactive oxygen species (ROS) generation of human liver hepatocellular carcinoma (HepG2) cells induced by hydrogen peroxide $\left(\mathrm{H}_{2} \mathrm{O}_{2}\right)$. (A, C) ROS generation of HepG2 cells was measured the different incubated time by fluorescence microscope assay. (B, D) ROS generation of HepG2 cells was inhibited by four monomers at 15 min incubated time through fluorescence microscope assay. The data from three independent experiments are presented as the mean \pm standard deviation. ${ }^{* *} \mathrm{p}<0.01$, and ${ }^{* * *} \mathrm{p}<0.001$, the $\mathrm{H}_{2} \mathrm{O}_{2}$ vs. control group; ${ }^{\# \# \#} \mathrm{p}<$ 0.001 , the monomers vs. $\mathrm{H}_{2} \mathrm{O}_{2}$ group. 
br $\mathrm{m}, J=16.5 \mathrm{~Hz}, \mathrm{H}-3), 5.36(\mathrm{~d}, J=5.5 \mathrm{~Hz}, \mathrm{H}-6) ;{ }^{13} \mathrm{C}$ NMR $(100$ $\left.\mathrm{MHz}, \mathrm{CDCl}_{3}, \delta \mathrm{ppm}\right): \delta 140.78,121.71,71.82,56.09,55.99,50.17$, $45.88,42.24,42.33,39.80,37.33,37.27,37.27,33.98,32.42,31.93$, $31.69,29.20,28.90,25.82,24.37,24.31,23.10,21.10,19.81,19.39$, $18.98,11.98,11.86$. In comparison to the reference data [18], the ${ }^{1} \mathrm{H}$ NMR, ${ }^{13} \mathrm{C}$ NMR and MS data confirmed the white powder was $\beta$-sitosterol.

Compound 4 was white powder: $\mathrm{Mp} 235^{\circ} \mathrm{C}-240^{\circ} \mathrm{C} ;{ }^{1} \mathrm{H}$ NMR (400 MHz, DMSO-d $\left.\mathrm{d}_{6}, \delta \mathrm{ppm}\right): \delta 6.92(2 \mathrm{H}, \mathrm{s}, 2-\mathrm{H}, 6-\mathrm{H}), 8.82(\mathrm{H}$, s, 4-OH), 9.17 (2H, s, - $\mathrm{OH}), 12.22$ (1H, s, $-\mathrm{COOH}) ;{ }^{13} \mathrm{C}$ NMR (100 MHz, DMSO-d ${ }_{6}, \delta$ ppm): $\delta 167.90,145.87,138.45,120.93,109.20$. In comparison to the reference data [19], the ${ }^{1} \mathrm{H} N M R,{ }^{13} \mathrm{C}$ NMR confirmed the white powder was gallic acid.

\section{Effects of monomers on cell viability of HepG2 induced by $\mathrm{H}_{2} \mathrm{O}_{2}$}

Effect of paeonol, quercetin, $\beta$-sitosterol, gallic acid, and vitamin $\mathrm{E}$ and their doses on HepG2 cell viability were assessed through in vitro screening. As shown in Fig. 1A, compared to the control group, HepG2 cells viability began to decrease with the increase of monomers concentrations (as high as 40 and $80 \mu \mathrm{M}$ ) for $24 \mathrm{~h}$. In other words, the monomers were not cytotoxicity at 10 and $20 \mu \mathrm{M}$ on HepG2 cell. In order to compare the antioxidative effect of these monomers, subsequent experiments were uniformly administered at a concentration of $20 \mu \mathrm{M}$ in vitro. As illustrated in Fig. 1B, HepG2 cell viability showed a dose-response effect from $\mathrm{H}_{2} \mathrm{O}_{2}$ exposure, and $50 \%$ cell viability was obtained with $7 \mathrm{mM} \mathrm{H}_{2} \mathrm{O}_{2}$ treatment for $24 \mathrm{~h}$. As depicted in Fig. 1C, after pretreatment with the monomers at $20 \mu \mathrm{M}$ for $6 \mathrm{~h}$, and followed by stimulation with $7 \mathrm{mM} \mathrm{H}_{2} \mathrm{O}_{2}$ for $24 \mathrm{~h}$, the cell viability was increased in the monomers groups when compared with that of the $\mathrm{H}_{2} \mathrm{O}_{2}$ group.

\section{Inhibitory effects of monomers on ROS levels and antioxidant markers}

The inhibitory effect of four monomers against $\mathrm{H}_{2} \mathrm{O}_{2}$-induced oxidative stress was evaluated by the ROS levels and antioxidant markers of HepG2 cells. From Fig. 2A and 2C, the fluorescence intensity of ROS was the strongest in HepG2 cells induced by 7 $\mathrm{mM} \mathrm{H}_{2} \mathrm{O}_{2}$ for $15 \mathrm{~min}$. As shown in Fig. $2 \mathrm{~B}$ and 2D, the ROS intensity was reduced after the treatment of active monomers. In Table 2, the levels of T-AOC, SOD, and CAT were increased in the monomers groups and decreased in the $\mathrm{H}_{2} \mathrm{O}_{2}$ group. With respect to For the level of T-AOC, quercetin was much higher than the other monomers, as well as that of paeonol. As for the CAT level, paeonol had the best activities among monomers. This result revealed the orientation of the further animal experiment with the combined administration of paeonol and quercetin.

\section{Effects of monomers on the levels of Nrf2, $\mathrm{HO}-1$, and NQO1 expression of HepG2 cells}

The levels of Nrf2, HO-1, and NQO1 expression of HepG2 cells were analyzed using western blot. As depicted in Fig. 3A, the levels of Nrf2, HO-1, and NQO1 were distinctly increased after pretreatment with paeonol, quercetin, $\beta$-sitosterol, and gallic acid. In comparison with the model group, the level of Keap1 was suppressed. Monomers triggered the separation of Nrf2 from Keapl, and Nrf2 translocated from the cytosol to the nucleus (Fig. 3B). After pretreatment with monomers, Nrf2 levels were increased in the nucleus and reduced in the cytosol. EMSA technology was employed to assess the binding of Nrf2 to ARE. From Fig. 3C, Nrf2-ARE complexes was increased in the four monomer-treated groups.

\section{Activation of monomers on Nrf2/Keap1 signaling pathway in HepG2 cells}

The inhibitory mechanism of four monomers against oxidative stress was investigated through the Nrf2/Keap1 pathway. ML385 as an inhibitory agent of Nrf2 was adopted to examine the expression of the downstream proteins related to this Nrf2/Keap1 pathway in HepG2 cells induced by $\mathrm{H}_{2} \mathrm{O}_{2}$. As described in Fig. 4, when ML385 was added to HepG2 cells, the level of Nrf2 was inhibited, and those of its downstream NQO1 and HO-1 were as well markedly decreased. The inhibitory effect of the monomers

Table 2. Antioxidative effects of active monomers on different parameters in HepG2 cells

\begin{tabular}{lccc}
\hline Parameter & T-AOC $\left(\mathrm{U} / 10^{6}\right.$ cell $)$ & SOD $(\mathrm{U} / \mathrm{mg})$ & CAT $\left(\mathrm{U} / 10^{6}\right.$ cell $)$ \\
\hline Control & $121.28 \pm 3.24$ & $30.41 \pm 1.00$ & $0.92 \pm 0.23$ \\
$\mathrm{H}_{2} \mathrm{O}_{2}$ & $81.75 \pm 0.01^{* *}$ & $19.43 \pm 0.33^{* *}$ & $0.23 \pm 0.01^{* *}$ \\
Paeonol & $99.72 \pm 1.80^{\# \#}$ & $19.05 \pm 0.53$ & $1.38 \pm 0.01^{\# \#}$ \\
Quercetin & $506.96 \pm 11.30^{\# \#}$ & $19.27 \pm 0.21$ & $0.61 \pm 0.26^{\#}$ \\
$\beta$-sitosterol & $68.27 \pm 1.56^{\# \#}$ & $26.83 \pm 0.34^{\# \#}$ & $1.07 \pm 0.26^{\# \#}$ \\
Gallic acid & $78.75 \pm 2.89$ & $28.62 \pm 0.52^{\# \#}$ & $0.84 \pm 0.13^{\# \#}$ \\
Vitamin E & $80.55 \pm 0.52$ & $21.96 \pm 3.91$ & $0.61 \pm 0.13^{\#}$ \\
\hline
\end{tabular}

Values are expressed as the mean \pm standard deviation. HepG2, human liver hepatocellular carcinoma; T-AOC, total antioxidant capacity; SOD, superoxide dismutase; CAT, catalase; $\mathrm{H}_{2} \mathrm{O}_{2}$, hydrogen peroxide. ${ }^{* *} \mathrm{p}<0.01$, the $\mathrm{H}_{2} \mathrm{O}_{2}$ vs. control group; ${ }^{*} \mathrm{p}<0.05$ and ${ }^{* \sharp} \mathrm{p}$ $<0.01$, the chemicals vs. $\mathrm{H}_{2} \mathrm{O}_{2}$ group. 
A
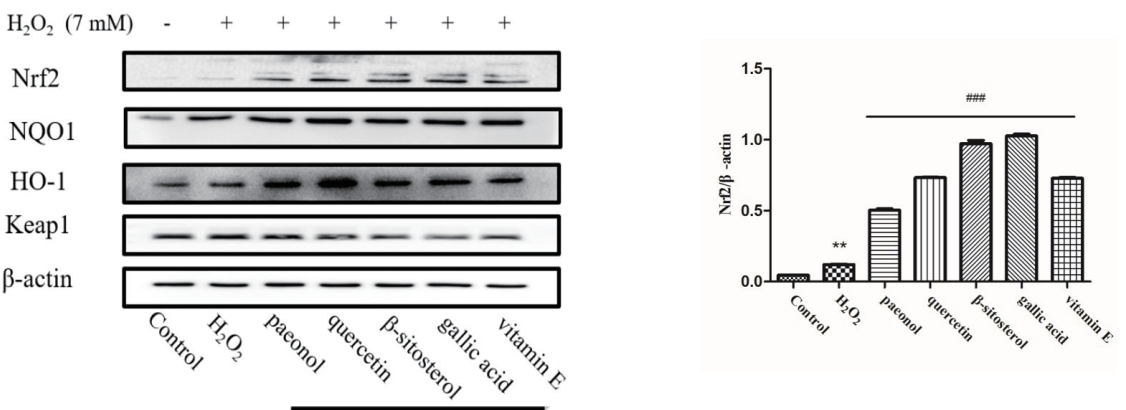

$(20 \mu \mathrm{M})$
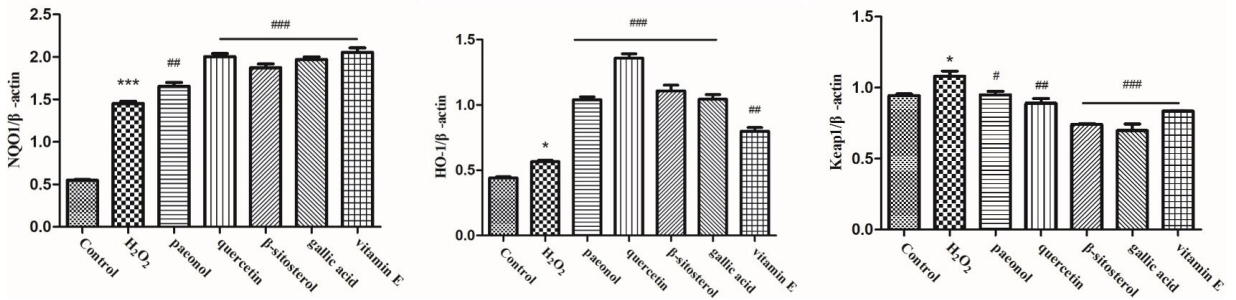

B

Cytosol
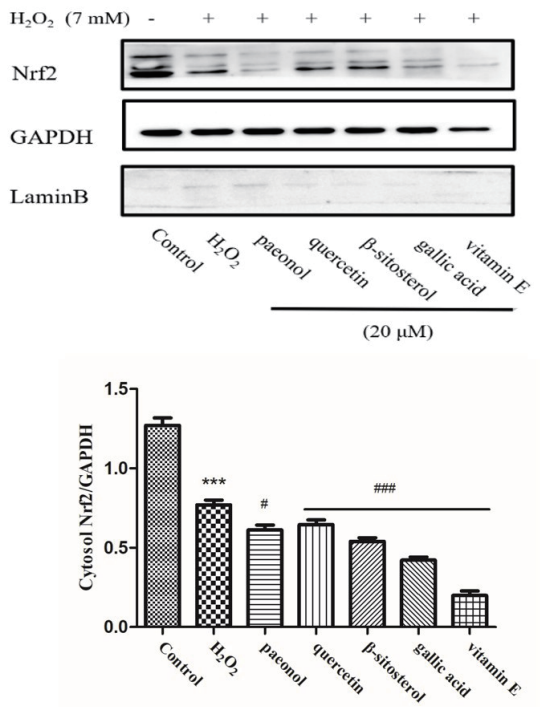

\section{C}

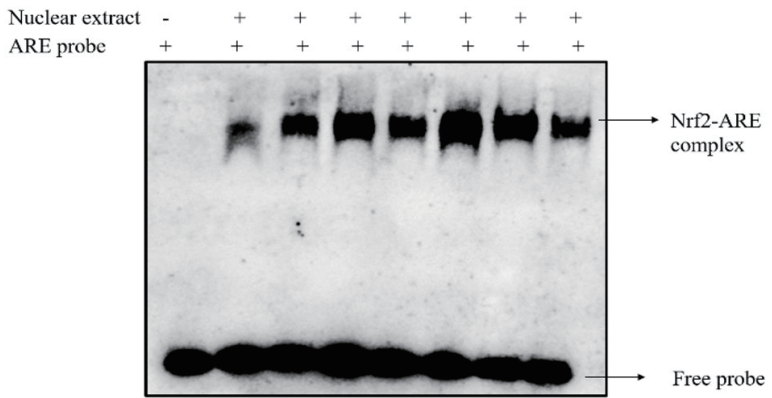
ARE probe

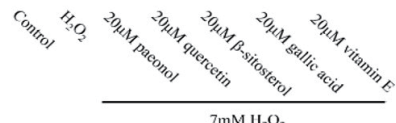

Nucleus
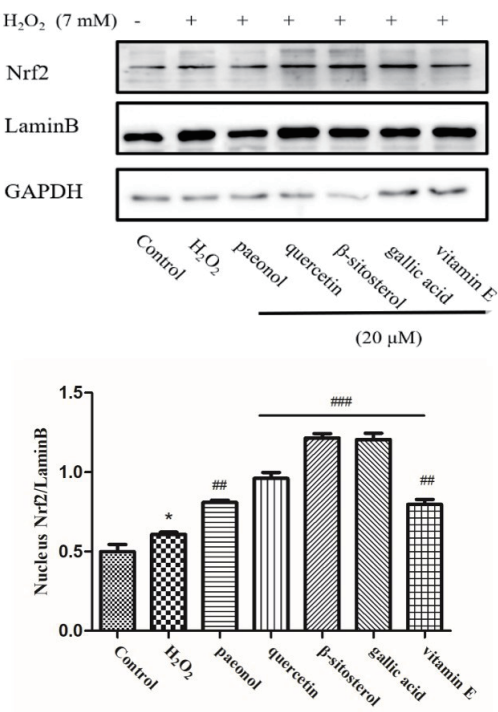

Fig. 3. Activation of four monomers on the Kelch-like ECH-associated protein 1 (Keap1)/nuclear factor E2-related factor 2 (Nrf2) signaling pathway in human liver hepatocellular carcinoma (HepG2) cells induced by hydrogen peroxide $\left(\mathrm{H}_{2} \mathrm{O}_{2}\right)$. (A) The levels of Nrf2, Keap1, NQO1, and HO-1 expressions were measured by western blot assay. (B) Translocation of Nrf2 protein from the cytosol to the nucleus was also evaluated by western blot assay. (C) Effects of four monomers on the binding capacities of Nrf2-ARE complexes in HepG2 cells after $\mathrm{H}_{2} \mathrm{O}_{2}$ treatment. The data from three independent experiments are presented as the mean \pm standard deviation. NQO1, quinone oxidoreductase 1 ; $\mathrm{HO}-1$, heme oxygenase-1; ARE, antioxidant-responsive element. ${ }^{*} p<0.05,{ }^{* *} p<0.01$, and ${ }^{* * *} p<0.001$, the $\mathrm{H}_{2} \mathrm{O}_{2}$ vs. control group; ${ }^{p} \mathrm{p}<0.05$, ${ }^{\#} \mathrm{p}<$ 0.01 , and ${ }^{\# \#} \mathrm{p}<0.001$, the monomers vs. $\mathrm{H}_{2} \mathrm{O}_{2}$ group. 


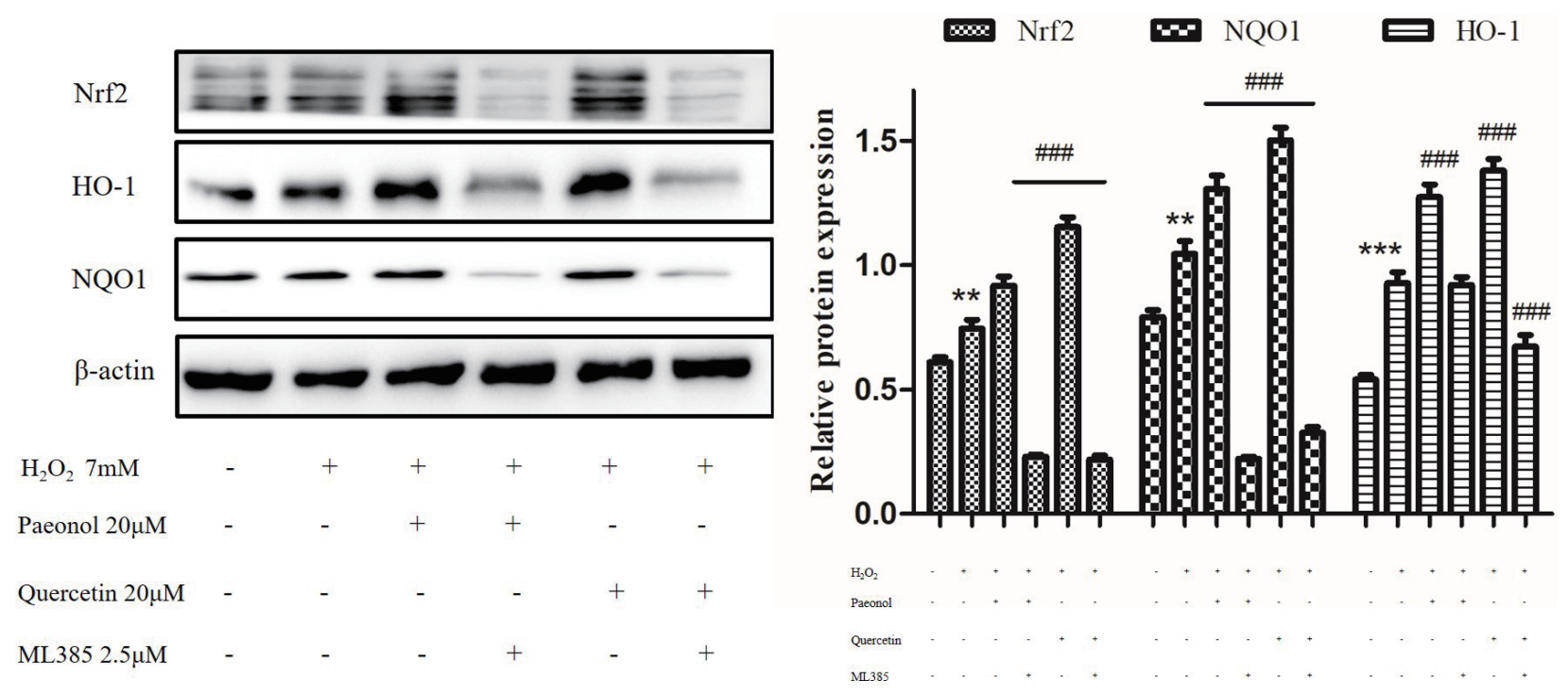

Fig. 4. The expressions of Nrf2, NQO1, and HO-1 proteins were determined in the presence or absence of paeonol, quercetin and ML385 in HepG2 cells induced by $\mathrm{H}_{2} \mathrm{O}_{2}$. The data from three independent experiments are presented as the mean \pm standard deviation. Nrf2, nuclear factor E2-related factor 2; NQO1, quinone oxidoreductase 1; $\mathrm{HO}-1$, heme oxygenase-1; HepG2, human liver hepatocellular carcinoma; $\mathrm{H}_{2} \mathrm{O}_{2}$, hydrogen peroxide. ${ }^{* *} \mathrm{p}<0.01$, and ${ }^{* * *} \mathrm{p}<0.001$, the $\mathrm{H}_{2} \mathrm{O}_{2}$ vs. control group; ${ }^{\# \# *} \mathrm{p}<0.001$, the monomers vs. $\mathrm{H}_{2} \mathrm{O}_{2}$ group.

on oxidative stress was perhaps related to the Nrf2/ Keap1 pathway in HepG2 cells.

\section{Effect of monomers on mice histopathological change and hepatic damage induced by $\mathrm{CCl}_{4}$}

Histopathological change and hepatic damage were evaluated by using H\&E staining and commercial kits (Fig. 5). The H\&E staining of mice liver tissue (Fig. 5A) showed that mice liver histology induced by the intraperitoneal injection of $\mathrm{CCl}_{4}$ was significantly changed and accompanied with central venous hyperemia, inflammatory infiltration, and hepatocyte necrosis. By contrast, pretreatment with the monomers effectively prevented the development of histopathological changes. The activities of AST and ALT were measured to evaluate the hepatic damage (Fig. 5B, C). The levels of ALT, AST, and the AST/ALT ratio were facilitated in the liver injury group and were decreased in the monomers-treated groups. The levels of GSH and SOD were reduced in the $\mathrm{CCl}_{4}$ group and were increased in the monomer groups (Fig. 5E, F). Paeonol distinctly ameliorated the liver injury, and quercetin slightly alleviated liver damage. Hence, the synergistic effects of paeonol and quercetin were not observed in mice stimulated by $\mathrm{CCl}_{4}$.

\section{Effect of monomers on levels of Nrf2 and HO-1 expression in mice stimulated by $\mathrm{CCl}_{4}$}

As described in Fig. 6A, compared to the model group, the Nrf2 level was increased in the paeonol group by immunohistochemical staining analysis. From Fig. 6B, the levels of Nrf2 and HO-1 of mice liver tissues were mildly increased in the $\mathrm{CCl}_{4}$ group and were apparently upregulated in paeonol, quercetin, L-(paeonol + quercetin) and $\mathrm{H}$-(paeonol + quercetin) groups. However, the effect of paeonol was still better than that of quercetin, and the synergistic effect was not found in this study.

\section{DISCUSSION}

Paeonol, quercetin, $\beta$-sitosterol, and gallic acid extracted from MC had the antioxidative, anti-inflammatory, antifungal, antimetastatic activities [20-25]. However, their inhibitory mechanisms against oxidative stress induced by $\mathrm{H}_{2} \mathrm{O}_{2}$ in $\mathrm{HepG} 2$ cells in vitro, and liver damage stimulated by $\mathrm{CCl}_{4}$ in mice in vivo, and whether they exhibited their inhibitory effects were independent or synergy were still unknown. Our study suggested that four monomers had antioxidative capacities in vitro and in vivo. Furthermore, the inhibitory effects of the four monomers were independent and not synergistic in response to liver injury, and the potential mechanism mainly depended on the regulation $\mathrm{Nrf2/}$ Keapl signaling pathway.

There was evidence proved that oxidative stress induced by $\mathrm{H}_{2} \mathrm{O}_{2}$ caused the self-generation of ROS [26]. Our study found that ROS was produced and ultimately led to cell death in the $\mathrm{H}_{2} \mathrm{O}_{2}$ group. The excessive ROS was evidently depleted with pretreatment with four monomers. Along with the continuous production of ROS, cellular innate antioxidant systems were inadequate to alleviate oxidative stress; thus, phase II defense enzymes and antioxidant proteins, such as enzymatic and antioxidants, were upregulated and played an essential role in reducing ROS $[27,28]$. SOD converted superoxide radicals into $\mathrm{H}_{2} \mathrm{O}_{2}$, while $\mathrm{CAT}$ degraded $\mathrm{H}_{2} \mathrm{O}_{2}$ into water and oxygen [29]. GSH was 
A

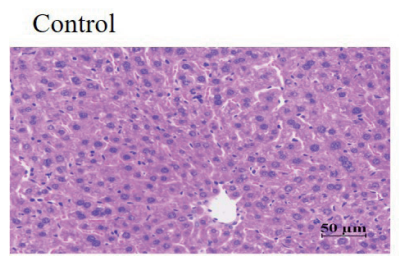

Quercetin

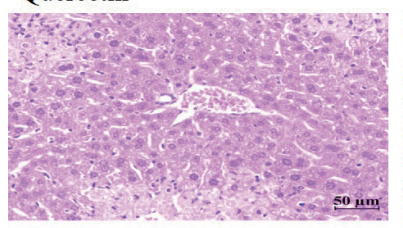

B

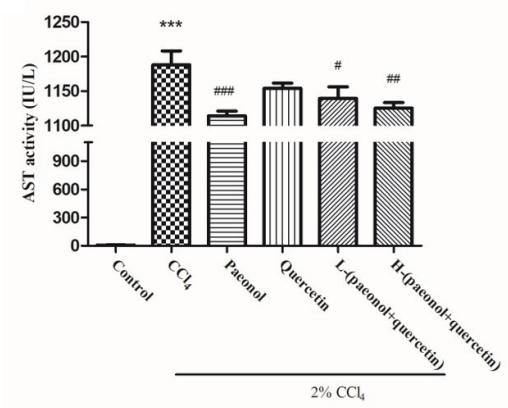

E

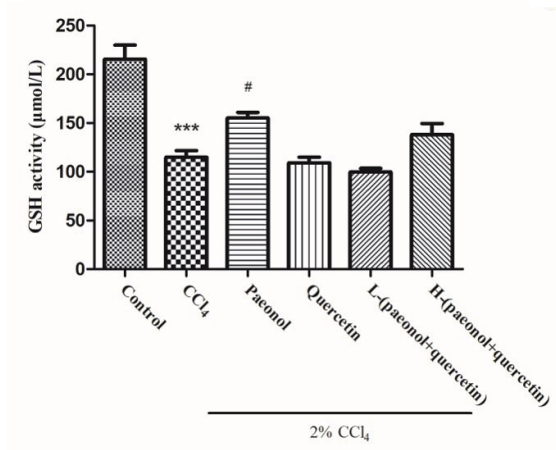

$\mathrm{CCl}_{4}$

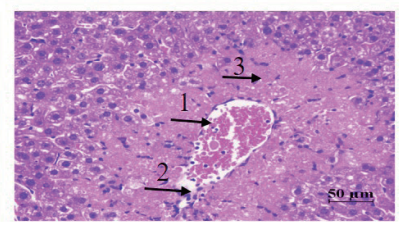

L-(paeonol+quercetin)

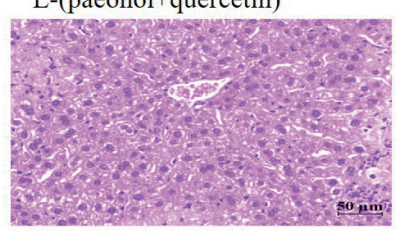

C

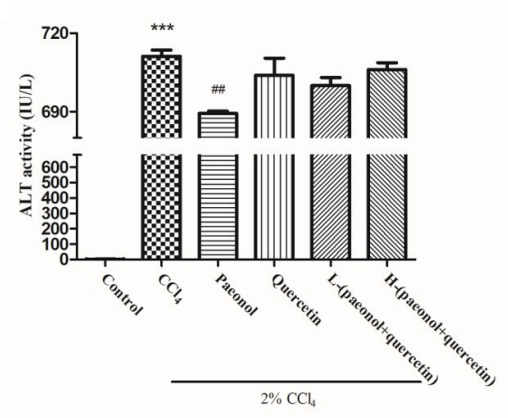

$\mathbf{F}$

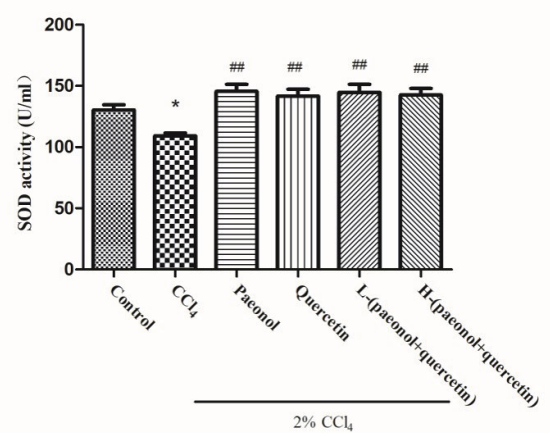

Paeonol

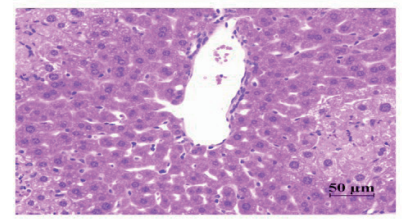

$\mathrm{H}-($ paeonol+quercetin)

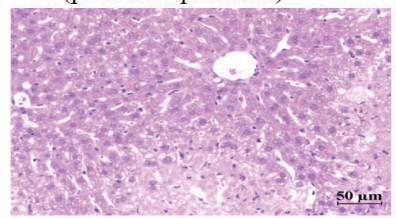

D

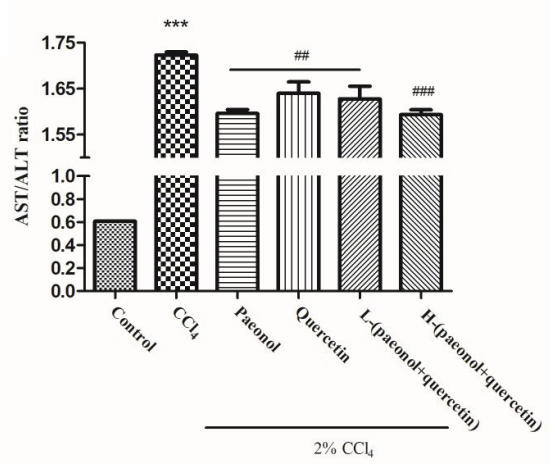

Fig. 5. Effects of separate or combined administration of paeonol and quercetin on liver tissues and serum markers of mice after carbon tetrachloride $\left(\mathrm{CCl}_{4}\right)$ intraperitoneal injection. (A) Representative histopathological changes in mice livers were observed with $\mathrm{H \& E}$ staining. Magnification $200 \times$ (1, central venous hyperemia; 2, inflammatory infiltration; 3, hepatocyte necrosis). (B-F) Effects of active monomers on the levels of AST, ALT, AST/ALT ratio, GSH, and SOD in mice serums induced by $\mathrm{CCl}_{4}$. Paeonol and quercetin groups were pretreated with $100 \mathrm{mg} / \mathrm{kg} \mathrm{paeonol} \mathrm{and} 100 \mathrm{mg} /$ $\mathrm{kg}$ quercetin, respectively. L-(paeonol + quercetin) group was pretreated with $50 \mathrm{mg} / \mathrm{kg}$ paeonol and $50 \mathrm{mg} / \mathrm{kg}$ quercetin. $\mathrm{H}$-(paeonol + quercetin) group was pretreated with $100 \mathrm{mg} / \mathrm{kg}$ paeonol and $100 \mathrm{mg} / \mathrm{kg}$ quercetin. The data from three independent experiments are presented as the mean \pm standard deviation. AST, aspartate aminotransferase; ALT, alanine transaminase; GSH, glutathione; SOD, superoxide dismutase. ${ }^{*} p<0.05$, ${ }^{* * *} \mathrm{p}<0.001$, the $\mathrm{CCl}_{4}$ vs. control group; ${ }^{\mathrm{p}}<0.05$, $\# \mathrm{p}<0.01$, and ${ }^{\# \#} \mathrm{p}<0.001$, the monomers vs. $\mathrm{CCl}_{4}$ group.

a low-molecular-weight free radical scavenger that had been implicated in oxidative damage [30]. T-AOC had been recognized as a critical index of oxidative defense [31]. Our results showed that antioxidants markers were reduced in the $\mathrm{H}_{2} \mathrm{O}_{2}$ group and were increased in the monomer groups. The hepatotoxicity induced by $\mathrm{CCl}_{4}$ converted to trichloromethyl peroxyl radical [7,32]. The reduction of ROS or inhibition of hepato-toxicity was a good strategy for the prevention of acute liver injury [33-35]. In our study, after the mice were treated with $\mathrm{CCl}_{4}$, the phenomina of central venous hyperemia, inflammatory infiltration and hepatocyte ne- crosis in mice liver would be occurred. The levels of ALT and AST and the ratio of AST/ALT were elevated, and the activities of SOD and GSH were decreased in the model group. Administration of paeonol, quercetin, L-(paeonol + quercetin), and $\mathrm{H}$-(paeonol + quercetin) prevented liver injury induced by $\mathrm{CCl}_{4}$. Furthermore, histopathological changes were effectively attenuated in the paeonol group but not in the combined paeonol and quercetin group. Obviously, scavenging excessive ROS, increasing the levels of antioxidative enzymes, inhibiting hepatotoxicity, and resisting cell death were beneficial for alleviating oxidative damage and liver 
A
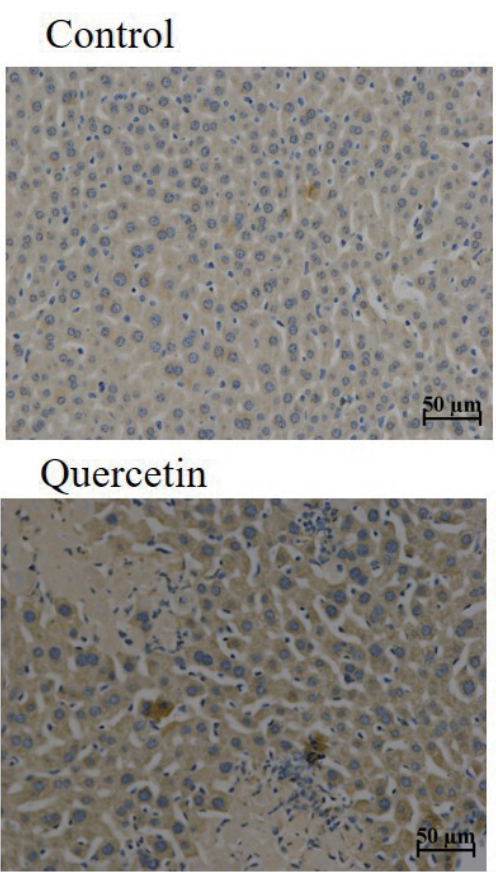

$\mathrm{CCl}_{4}$

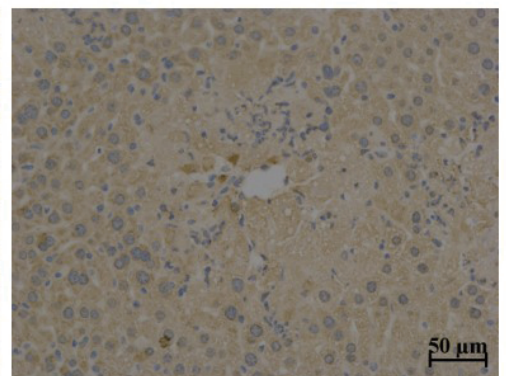

L-(paeonol+quercetin)

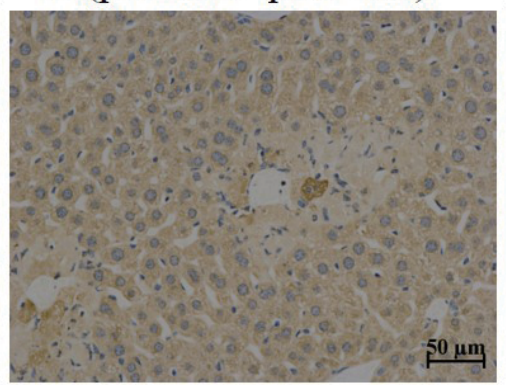

\section{Paeonol}

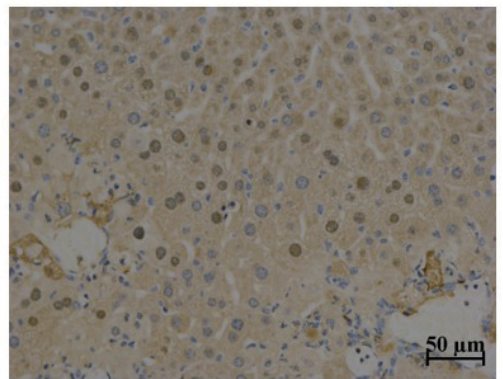

$\mathrm{H}-($ paeonol+quercetin)

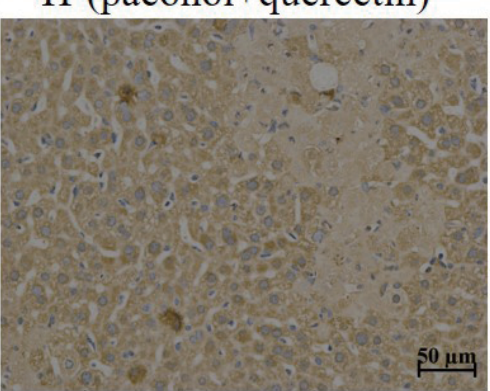

B
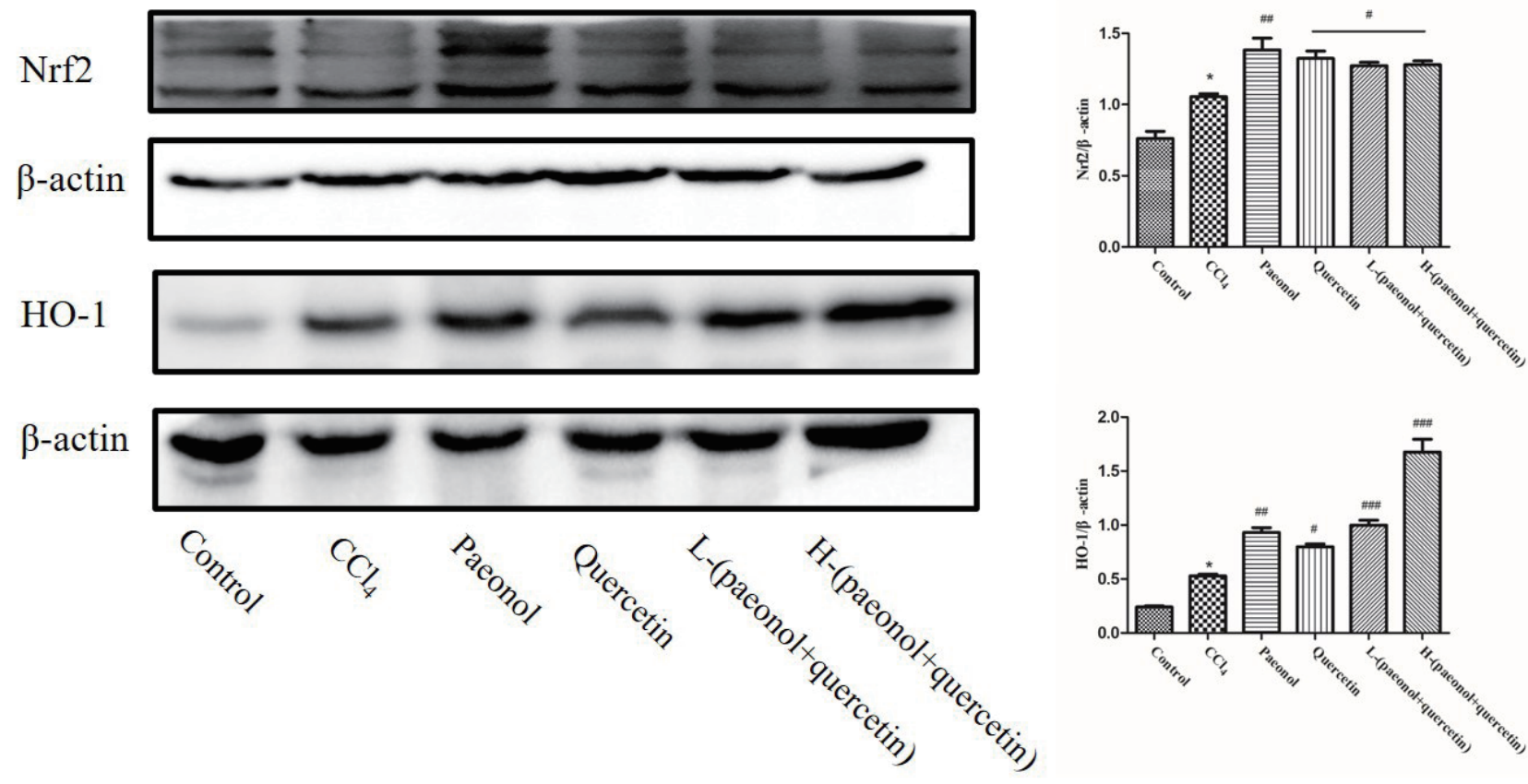

\section{$2 \% \mathrm{CCl}_{4}$}

Fig. 6. Effects of separate or combined administration of paeonol and quercetin on the expressions of nuclear factor E2-related factor 2 (Nrf2) and heme oxygenase-1 (HO-1) proteins in mice livers induced by carbon tetrachloride $\left(\mathrm{CCl}_{4}\right)$. (A) Representative changes of Nrf2 in mice livers were obtained by immunohistochemical staining assay (magnification 200X). (B) The expressions of Nrf2 and HO-1 proteins were detected by western blot. The data from three independent experiments are presented as the mean \pm standard deviation. ${ }^{*} \mathrm{p}<0.05$, the $\mathrm{CCl}_{4}$ vs. control group; ${ }^{*} \mathrm{p}<0.05$, \#\# $<0.01$, and ${ }^{\# \#} \mathrm{p}<0.001$, the monomers vs. $\mathrm{CCl}_{4}$ group.

injury.

Nrf2 belonged to a small family of transcription factors that induced a set of antioxidant and detoxication enzymes [36]. In resting cells, Nrf2 was anchored in the cytoplasm by repressor protein Keap1, which triggered the degradation of Nrf2 [37]. Under oxidative or electrophilic stress, the majority of cytoprotective proteins were regulated by Nrf2. The dissociation of Nrf2 from Keap1 migrated to the nucleus, which triggered the activation 
of Nrf2-dependent transcription of ARE-responsive genes; this pathway seemed to be a strategy for augmenting the antioxidant defense $[38,39]$. Nrf2 was a highly unstable protein $\left(\mathrm{t}_{1 / 2}-15 \mathrm{~min}\right)$. After the administration of the drug, Nrf2 levels first increased and later decreased in the nucleus; the highest level of Nrf2 was observed at $6 \mathrm{~h}$ [40]. Therefore, here Nrf2 level in the nucleus was measured after the administration of monomers for $6 \mathrm{~h}$. Monomers pretreatment blocked Keap1, remarkably upregulated Nrf2 expression, promoted accumulation of Nrf2 in the nucleus, and increased the binding between Nrf2 and ARE in HepG2 cells treated with $\mathrm{H}_{2} \mathrm{O}_{2}$. Meanwhile, paeonol, quercetin, L-(paeonol + quercetin), and $\mathrm{H}$-(paeonol + quercetin) group increased Nrf2 expression in $\mathrm{CCl}_{4}$-induced mice. $\mathrm{HO}-1$, which served as the primary antioxidative responder, was one of the key target genes of the Nrf2/Keap1 pathway [41,42]. NQO1 was a ubiquitous flavoprotein and a pivotal cytoprotective enzyme; it was responsible for converting reactive quinones (oxidants) to relatively stable hydroquinones [43]. Additionally, NQO1 was considered as a second antioxidative effector in the Nrf2/Keap1 pathway [44]. Our data demonstrated that pretreatment with active monomers sharply enhanced Nrf2 and HO-1 levels in the in vitro and in vivo experiments. ML385 was used to inhibit the transcription of the Nrf2 gene in HepG2 cells. After ML385 was adopted in this study, the HO-1 and NQO1 levels were inhibited as the Nrf2 level was reduced. The protective mechanism of these monomers against $\mathrm{H}_{2} \mathrm{O}_{2}$-induced oxidative stress and $\mathrm{CCl}_{4}$-induced liver injury was mediated by the activation of the Nrf2/Keap1 signaling pathway.

In conclusion, pretreatment with paeonol, quercetin, $\beta$-sitosterol, and gallic acid attenuated oxidative stress in HepG2 cells, paeonol and quercetin exhibited a more significant alleviation on liver injury in mice. The underlying mechanism of the active monomers from $\mathrm{MC}$ against oxidative stress is the suppression of ROS generation, the attenuation of histological damage, up-regulation antioxidative enzymes and proteins, and the activation Nrf2/Keapl signaling pathway. Meanwhile, our data proved that the inhibitory effects of paeonol and quercetin were independent, not synergistic in the liver injury of mice model.

\section{ACKNOWLEDGEMENTS}

This work was supported by the Fundamental Research Funds for the Central Universities (XDJK2020B056), and the National Key Research and Development Program of China for Traditional Chinese Medicine Modernization (2017YFC1702605, 2017YFC1702606).

\section{CONFLICTS OF INTEREST}

The authors declare no conflicts of interest.

\section{SUPPLEMENTARY MATERIALS}

Supplementary data including two figures can be found with this article online at http://pdf.medrang.co.kr/paper/pdf/Kjpp/ Kjpp2020-24-05-01-s001.pdf.

\section{REFERENCES}

1. Yu BP. Cellular defenses against damage from reactive oxygen species. Physiol Rev. 1994;74:139-162.

2. Berndt C, Lillig CH, Flohé L. Redox regulation by glutathione needs enzymes. Front Pharmacol. 2014;5:168.

3. Wang P, Gao YM, Sun X, Guo N, Li J, Wang W, Yao LP, Fu YJ. Hepatoprotective effect of 2'-O-galloylhyperin against oxidative stressinduced liver damage through induction of Nrf2/ARE-mediated antioxidant pathway. Food Chem Toxicol. 2017;102:129-142.

4. Zitka O, Skalickova S, Gumulec J, Masarik M, Adam V, Hubalek J, Trnkova L, Kruseova J, Eckschlager T, Kizek R. Redox status expressed as GSH:GSSG ratio as a marker for oxidative stress in paediatric tumour patients. Oncol Lett. 2012;4:1247-1253.

5. Lin TA, Ke BJ, Cheng CS, Wang JJ, Wei BL, Lee CL. Red quinoa bran extracts protects against carbon tetrachloride-induced liver injury and fibrosis in mice via activation of antioxidative enzyme systems and blocking TGF- $\beta 1$ pathway. Nutrients. 2019;11:395.

6. Taguchi K, Motohashi H, Yamamoto M. Molecular mechanisms of the Keap1-Nrf2 pathway in stress response and cancer evolution. Genes Cells. 2011;16:123-140.

7. Su C, Xia X, Shi Q, Song X, Fu J, Xiao C, Chen H, Lu B, Sun Z, Wu S, Yang S, Li X, Ye X, Song E, Song Y. Neohesperidin dihydrochalcone versus $\mathrm{CCl}_{4}$-induced hepatic injury through different mechanisms: the implication of free radical scavenging and Nrf2 activation. $J$ Agric Food Chem. 2015;63:5468-5475.

8. Liu J, Sun H, Zhang A, Yan G, Han Y, Xue C, Zhou X, Shi H, Wang X. Serum pharmacochemistry combined with multiple data processing approach to screen the bioactive components and their metabolites in Mutan Cortex by ultra-performance liquid chromatography tandem mass spectrometry. Biomed Chromatogr. 2014;28:500-510.

9. Lin MY, Lee YR, Chiang SY, Li YZ, Chen YS, Hsu CD, Liu YW. Cortex Moutan induces bladder cancer cell death via apoptosis and retards tumor growth in mouse bladders. Evid Based Complement Alternat Med. 2013;2013:207279.

10. Oh GS, Pae HO, Oh H, Hong SG, Kim IK, Chai KY, Yun YG, Kwon TO, Chung HT. In vitro anti-proliferative effect of 1,2,3,4,6-pentaO-galloyl-beta-D-glucose on human hepatocellular carcinoma cell line, SK-HEP-1 cells. Cancer Lett. 2001;174:17-24.

11. Chen G, Zhang L, Zhu Y. Determination of glycosides and sugars in Moutan Cortex by capillary electrophoresis with electrochemical detection. J Pharm Biomed Anal. 2006;41:129-134.

12. Li J, Li Y, Pan S, Zhang L, He L, Niu Y. Paeonol attenuates ligationinduced periodontitis in rats by inhibiting osteoclastogenesis via regulating Nrf2/NF- $\mathrm{B} / \mathrm{NFATc1}$ signaling pathway. Biochimie. 2019;156:129-137.

13. Li XY, Xu JD, Zhou SS, Kong M, Xu YY, Zou YT, Tang Y, Zhou L, $\mathrm{Xu} \mathrm{MZ}, \mathrm{Xu}$ J, Li SL. Time segment scanning-based quasi-multiple reaction monitoring mode by ultra-performance liquid chromatog- 
raphy coupled with quadrupole/time-of-flight mass spectrometry for quantitative determination of herbal medicines: Moutan Cortex, a case study. J Chromatogr A. 2018;1581-1582:33-42.

14. Feng RB, Wang Y, He C, Yang Y, Wan JB. Gallic acid, a natural polyphenol, protects against tert-butyl hydroperoxide- induced hepatotoxicity by activating ERK-Nrf2-Keap1-mediated antioxidative response. Food Chem Toxicol. 2018;119:479-488.

15. Peng Z, Gong X, Yang Y, Huang L, Zhang Q, Zhang P, Wan R, Zhang B. Hepatoprotective effect of quercetin against LPS/d-GalN induced acute liver injury in mice by inhibiting the IKK/NF- $\mathrm{KB}$ and MAPK signal pathways. Int Immunopharmacol. 2017;52:281-289.

16. Chen F, Mo K, Zhang Q, Fei S, Zu Y, Yang L. A novel approach for distillation of paeonol and simultaneous extraction of paeoniflorin by microwave irradiation using an ionic liquid solution as the reaction medium. Sep Purif Technol. 2017;183:73-82.

17. Li YL, Li J, Wang NL, Yao XS. Flavonoids and a new polyacetylene from Bidens parviflora Willd. Molecules. 2008;13:1931-1941.

18. Li WH, Chang ST, Chang SC, Chang HT. Isolation of antibacterial diterpenoids from Cryptomeria japonica bark. Nat Prod Res. 2008;22:1085-1093.

19. He L, She Z. Molecular structure identification and properties of gallic acid from galla chinensis. Chem Fiber Text Techol. 2017;46:5-9.

20. Sun X, Wang P, Yao LP, Wang W, Gao YM, Zhang J, Fu YJ. Paeonol alleviated acute alcohol-induced liver injury via SIRT1/Nrf2/NF-кB signaling pathway. Environ Toxicol Pharmacol. 2018;60:110-117.

21. Surh YJ. Cancer chemoprevention with dietary phytochemicals. Nat Rev Cancer. 2003;3:768-780.

22. Pinheiro-Sant'ana HM, Guinazi M, Oliveira Dda S, Della Lucia CM, Reis Bde L, Brandão SC. Method for simultaneous analysis of eight vitamin $\mathrm{E}$ isomers in various foods by high performance liquid chromatography and fluorescence detection. J Chromatogr A. 2011;1218:8496-8502.

23. Yen GC, Duh PD, Tsai HL. Antioxidant and pro-oxidant properties of ascorbic acid and gallic acid. Food Chem. 2002;79:307-313.

24. Ho HH, Chang CS, Ho WC, Liao SY, Wu CH, Wang CJ. Anti-metastasis effects of gallic acid on gastric cancer cells involves inhibition of NF-kappaB activity and downregulation of PI3K/AKT/small GTPase signals. Food Chem Toxicol. 2010;48:2508-2516.

25. Hsiang CY, Hseu YC, Chang YC, Kumar KJ, Ho TY, Yang HL. Toona sinensis and its major bioactive compound gallic acid inhibit LPS-induced inflammation in nuclear factor- $\kappa \mathrm{B}$ transgenic mice as evaluated by in vivo bioluminescence imaging. Food Chem. 2013; 136:426-434.

26. Sies H, Berndt C, Jones DP. Oxidative stress. Annu Rev Biochem. 2017;86:715-748.

27. Wei S, Chi J, Zhou M, Li R, Li Y, Luo J, Kong L. Anti-inflammatory lindenane sesquiterpeniods and dimers from Sarcandra glabra and its upregulating AKT/Nrf2/HO-1 signaling mechanism. Ind Crops Prod. 2019;137:367-376.

28. Chen B, Lu Y, Chen Y, Cheng J. The role of Nrf2 in oxidative stressinduced endothelial injuries. J Endocrinol. 2015;225:R83-R99.

29. Zhuang Y, Ma Q, Guo Y, Sun L. Protective effects of rambutan (Nephelium lappaceum) peel phenolics on $\mathrm{H}_{2} \mathrm{O}_{2}$-induced oxidative damages in HepG2 cells and D-galactose-induced aging mice. Food
Chem Toxicol. 2017;108(Pt B):554-562.

30. Lyu Z, Ji X, Chen G, An B. Atractylodin ameliorates lipopolysaccharide and $\mathrm{D}$-galactosamine-induced acute liver failure via the suppression of inflammation and oxidative stress. Int Immunopharmacol. 2019;72:348-357.

31. Auten RL, Davis JM. Oxygen toxicity and reactive oxygen species: the devil is in the details. Pediatr Res. 2009;66:121-127.

32. Weber LW, Boll M, Stampfl A. Hepatotoxicity and mechanism of action of haloalkanes: carbon tetrachloride as a toxicological model. Crit Rev Toxicol. 2003;33:105-136.

33. Pham-Huy LA, He H, Pham-Huy C. Free radicals, antioxidants in disease and health. Int J Biomed Sci. 2008;4:89-96.

34. Johnston DE, Kroening C. Mechanism of early carbon tetrachloride toxicity in cultured rat hepatocytes. Pharmacol Toxicol. 1998; 83:231-239.

35. Vuda M, D'Souza R, Upadhya S, Kumar V, Rao N, Kumar V, Boillat C, Mungli P. Hepatoprotective and antioxidant activity of aqueous extract of Hybanthus enneaspermus against CCl4-induced liver injury in rats. Exp Toxicol Pathol. 2012;64:855-859.

36. Itoh K, Chiba T, Takahashi S, Ishii T, Igarashi K, Katoh Y, Oyake T, Hayashi N, Satoh K, Hatayama I, Yamamoto M, Nabeshima Y. An Nrf2/small Maf heterodimer mediates the induction of phase II detoxifying enzyme genes through antioxidant response elements. Biochem Biophys Res Commun. 1997;236:313-322.

37. Chun KS, Kundu J, Kundu JK, Surh YJ. Targeting Nrf2-Keap1 signaling for chemoprevention of skin carcinogenesis with bioactive phytochemicals. Toxicol Lett. 2014;229:73-84.

38. Keum YS. Regulation of the Keap1/Nrf2 system by chemopreventive sulforaphane: implications of posttranslational modifications. Ann N Y Acad Sci. 2011;1229:184-189.

39. Lou Y, Guo Z, Zhu Y, Kong M, Zhang R, Lu L, Wu F, Liu Z, Wu J. Houttuynia cordata Thunb. and its bioactive compound 2-undecanone significantly suppress benzo(a)pyrene-induced lung tumorigenesis by activating the Nrf2-HO-1/NQO-1 signaling pathway. $J$ Exp Clin Cancer Res. 2019;38:242.

40. Nguyen T, Nioi P, Pickett CB. The Nrf2-antioxidant response element signaling pathway and its activation by oxidative stress. J Biol Chem. 2009;284:13291-13295.

41. Calabrese V, Cornelius C, Dinkova-Kostova AT, Calabrese EJ, Mattson MP. Cellular stress responses, the hormesis paradigm, and vitagenes: novel targets for therapeutic intervention in neurodegenerative disorders. Antioxid Redox Signal. 2010;13:1763-1811.

42. Bucolo C, Drago F, Maisto R, Romano GL, D'Agata V, Maugeri G, Giunta S. Curcumin prevents high glucose damage in retinal pigment epithelial cells through ERK1/2-mediated activation of the Nrf2/HO-1 pathway. JCell Physiol. 2019;234:17295-17304.

43. Sharath Babu GR, Anand T, Ilaiyaraja N, Khanum F, Gopalan N. Pelargonidin modulates Keap1/Nrf2 pathway gene expression and ameliorates citrinin-induced oxidative stress in HepG2 cells. Front Pharmacol. 2017;8:868.

44. Dinkova-Kostova AT, Talalay P. NAD(P)H:quinone acceptor oxidoreductase 1 (NQO1), a multifunctional antioxidant enzyme and exceptionally versatile cytoprotector. Arch Biochem Biophys. 2010; 501:116-123. 